\title{
STUDIES IN EDEMA. III. THE EFFECT OF PITRESSIN ON THE RENAL EXCRETION OF WATER AND ELECTROLYTES IN PATIENTS WITH AND WITHOUT LIVER DISEASE 1, 2
}

\author{
By ABRAHAM G. WHITE, 3, 4 GEORGE RUBIN, AND LOUIS LEITER \\ (From The Medical Division, Montefiore Hospital, New York City)
}

(Submitted for publication July 5, 1951 ; accepted August 13, 1951)

\section{INTRODUCTION}

Liver disease is often associated with abnormal water metabolism, as demonstrated by impaired water diuresis following oral hydration (1-4) and by water retention leading, at times, to edema and contributing, in part, to ascites formation.

Because the secretion of the posterior lobe of the pituitary inhibits the excretion of water, attempts have been made to relate this antidiuretic hormone $(\mathrm{ADH})$ to the water retention observed clinically in patients with liver disease. Thus there are several reports on an antidiuretic substance, found in greater amounts than in normals, in both the sera and urines of such patients (5-7). Although this substance (ADS) has been thought to represent the actual secretion of the posterior pituitary $(\mathrm{ADH})$, differences between the two, based chiefly upon the behavior of ADS and Pitressin on dialysis, have been reported. These differences have been summarized by Ames, Moore and Van Dyke, who have undertaken a more detailed characterization of urinary antidiuretic hormone secreted by the intact posterior pituitary gland (8). Their experiments indicate it is a large molecule as shown by its sedimentation in the ultracentrifuge.

One explanation for the observed increase in serum and urinary ADS in hepatic disease has been that the damaged liver may not sufficiently inactivate the antidiuretic hormone $(5,3,9)$. This supposition has been based on the demonstration in vitro that extracts of normal liver tissue have a

1 Presented in part before the Society of Experimental Medicine and Biology, New York Section, on February 7, 1951.

2 This study has been supported by a grant from the American Heart Association.

3 This work was done during the tenure of a Research Fellowship of the American Heart Association.

4 Present address: The Mount Sinai Hospital, New York City. marked ability to inactivate Pitressin (10-12), and that Pitressin injected into a site with hepatic portal drainage (in the rat) is less effective than that introduced into the general circulation (11). However, there has never been any conclusive evidence against the concept of overproduction of the posterior pituitary antidiuretic hormone in these patients.

Furthermore, the antidiuretic substance (ADS) may not be of posterior pituitary origin. It may be derived from some other source such as the liver-the hepatic VDM described by Shorr and associates (13), although the antidiuretic effect of VDM is probably mediated through the posterior pituitary since hypophysectomy abolishes its antidiuretic action (14).

Against the concept of an extra-posterior pituitary origin of urinary ADS is the fact that hypophysectomy has been reported to result in the disappearance of this substance from the urine (1517).

The multiplicity of methods of Pitressin or ADS assay (18-24) attests to the technical diffculties and lack of uniformity of results encountered in such procedures; some of these assay procedures have been summarized well by Ham (23).

Although the effect of the posterior pituitary antidiuretic hormone (ADH) on the excretion of water has been quite clearly defined, its effect on the excretion of electrolytes, especially the chloride ion, has not been described with equal unanimity.

An analysis of the pertinent literature $(23,25$ 39 ) indicates that the lack of agreement on this problem may be ascribed to several experimental variables: (a) types of extracts of the posterior pituitary lobe that have been administered; $(b)$ dosages used; $(c)$ routes of administration; $(d)$ species of experimental test organism; $(e)$ methods of expressing the changes in excretion of electrolytes following the administration of posterior 
pituitary fractions, either in terms of concentration $(\mathrm{mEq} . / 1)$ or in absolute quantity per unit time (mEq./min.).

The aims of this investigation have been: (1) to study water diuresis in patients with liver disease and in control subjects; (2) to develop a method of studying Pitressin antidiuresis, including a quantitative expression of such activity; (3) to analyze the response of hydrated patients with hepatic disease to intravenous Pitressin, in an attempt to test the hypothesis that the reported increase in serum and urinary ADS may be ascribable to decreased inactivation of the antidiuretic hormone; (4) to study the effect of Pitressin, injected intravenously in physiological dosage, on the concentrations of sodium, chloride, and potassium in the serum and urine in patients with liver disease and in control subjects.

\section{EXPERIMENTAL}

The responses of four patients (M. W., T. R., J. L., J. C.), with liver disease and seven control subjects without liver dysfunction to single intravenous doses of Pitressin were studied. The patients with liver disease included three with cirrhosis of the liver and ascites and one with active infectious hepatitis (see Appendix for clinical details). None of the 11 patients had any detectable renal disease.

Four experiments on two patients, (A. B., M. M.), with cirrhosis of the liver and one control subject were performed, using multiple intravenous doses of Pitressin instead of a single dose. Thus, a total of six $^{5}$ patients with liver disease and eight control subjects were studied.

Each subject was in a fasting state for 15 hours. Prior to the beginning of the experiment one glass of water was taken orally every half hour for two hours. An infusion of $5 \%$ glucose in water (average flow of 10 cc. per minute) was then started and continued throughout the entire experiment. When the rate of urine flow reached a plateau, $0.57 \mathrm{mU} / \mathrm{Kg}$. of Pitressin 6 was injected rapidly into the infusion tubing near the needle.

5 Since this paper was submitted for publication, Pitressin antidiuresis and intravenous hydration were studied in one patient (R. A.) with cirrhosis of the liver, and intravenous hydration alone was studied in two patients (B. N., T. McC.) with cirrhosis of the liver. The results were similar to those described herein. The experimental protocols for the nine patients are depicted graphically in Figure 5.

- Pitressin solution, N.N.R., 20 Pressor Units per cc. (Parke-Davis) Lot. No. G-C529M.
The urinary bladder was washed out with distilled water and air at the end of each collection period through an indwelling six-holed catheter.

Blood specimens were obtained at the beginning of an experiment, at the height of the diuresis, at the height of antidiuresis, and at the end of the procedure.

\section{CALCULATIONS AND DEFINITIONS}

The "antidiuresis period" equals the time from the injection of Pitressin until the reestablishment of the initial rate of urine flow which was observed when the hormone preparation was injected.

The antidiuretic effect of Pitressin was calculated as "per cent inhibition."

"Per cent inhibition"

$$
=\frac{\text { Expected diuresis minus observed diuresis } \times 100}{\text { Expected diuresis }} .
$$

The "observed diuresis" is the observed total urine flow during the period of the Pitressin effect described above. "Expected diuresis" minus the "observed diuresis" represents the "antidiuresis."

"Expected diuresis" is the urine flow that would have been obtained if the initial rate, observed when the Pitressin was injected, had been maintained throughout the period of Pitressin effect.

The "total hydration period" equals the time from the beginning of the infusion until the attainment of peak diuresis.

"Peak diuresis" was the maximum rate of urine flow attained during the period prior to the injection of Pitressin.

The "pre-Pitressin control period" (" $H$ " in Table VI), used for the calculation of the effect of Pitressin on the urinary excretion of electrolytes, is that period of time which just precedes the Pitressin injection, and which is equal to the "antidiuresis period" for a given patient. This calculation is made at the end of the experiment after the duration of the "antidiuresis period" has been determined.

The rate of excretion of each electrolyte was expressed in terms of $\mathrm{mEq} . / \mathrm{min}$. for the "hydration period" and for the "antidiuresis period." The series of "paired differences" for each patient was then subjected to statistical analysis.

\section{METHODS}

Hematocrit determinations on heparinized blood were performed by centrifuging in Wintrobe tubes at 2,500 r.p.m. for 30 minutes. Serum and urinary creatinine concentrations were measured by Peters' modification of the Folin method (40), urinary sodium and potassium and serum potassium with an internal standard Perkin 52A flame photometer, serum sodium by the Butler-Tuthill gravimetric method (41), chloride by the Van Slyke-Hiller modification of Sendroy's iodometric method (42), and urinary glucose by the method of Benedict (43). Standard methods of statistical analysis were employed (44). 


\section{RESULTS}

Results are presented in Figures 1-5 and Tables I-VII.

A. Excretion of water. There was no significant difference between the patients with liver dysfunction and the control subjects in the inhibition of diuresis produced by $0.57 \mathrm{mU}$ of Pitressin per $\mathrm{Kg}$. body weight. This inhibition averaged $54.3 \%$ for the 11 patients (Table I).

In addition, the two groups showed similar duration of Pitressin effect, 68.8 and 63.8 minutes for the experimental and control subjects, respectively (Table II).

The time required to reach peak diuresis averaged 94.5 minutes for the liver disease group as compared with an average of 85.1 minutes for the control group. This difference is not statistically significant (Table III).

Both groups also showed essentially similar peaks (cc./min.) of diuresis, as well as comparable average urine flows, $7.3 \mathrm{cc} . / \mathrm{min}$. and $7.6 \mathrm{cc}$./ min., during the "total hydration periods" (Table IV).

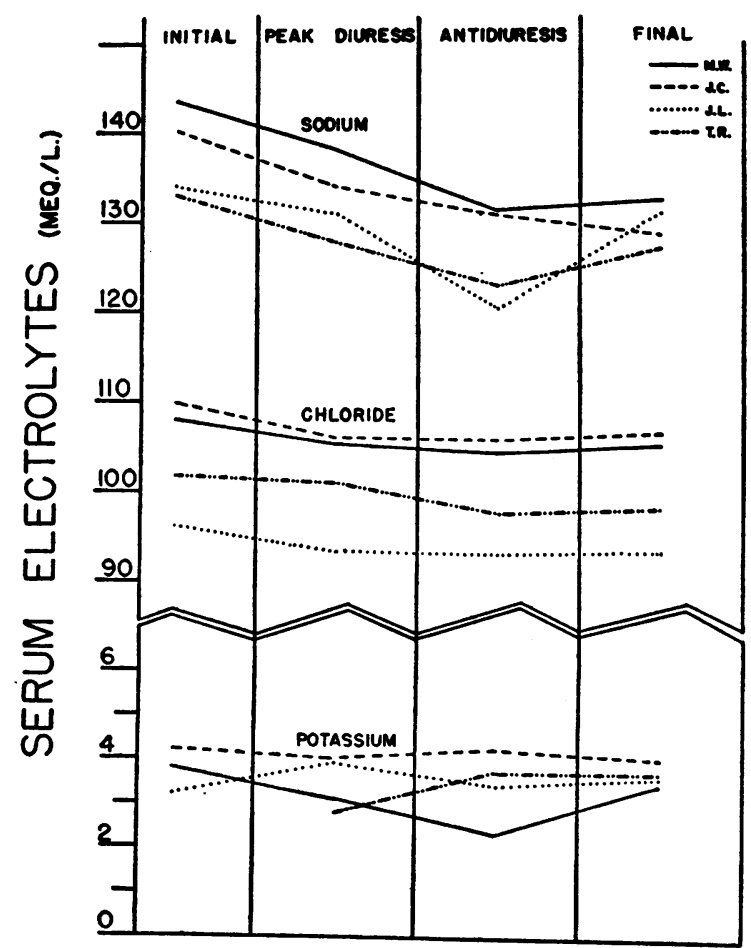

Fig. 1. The Effect of Intravenous Pitressin (0.57 mU/Kg.) ON the Concentrations of Serum Electrolytes in Patients with Liver Disease

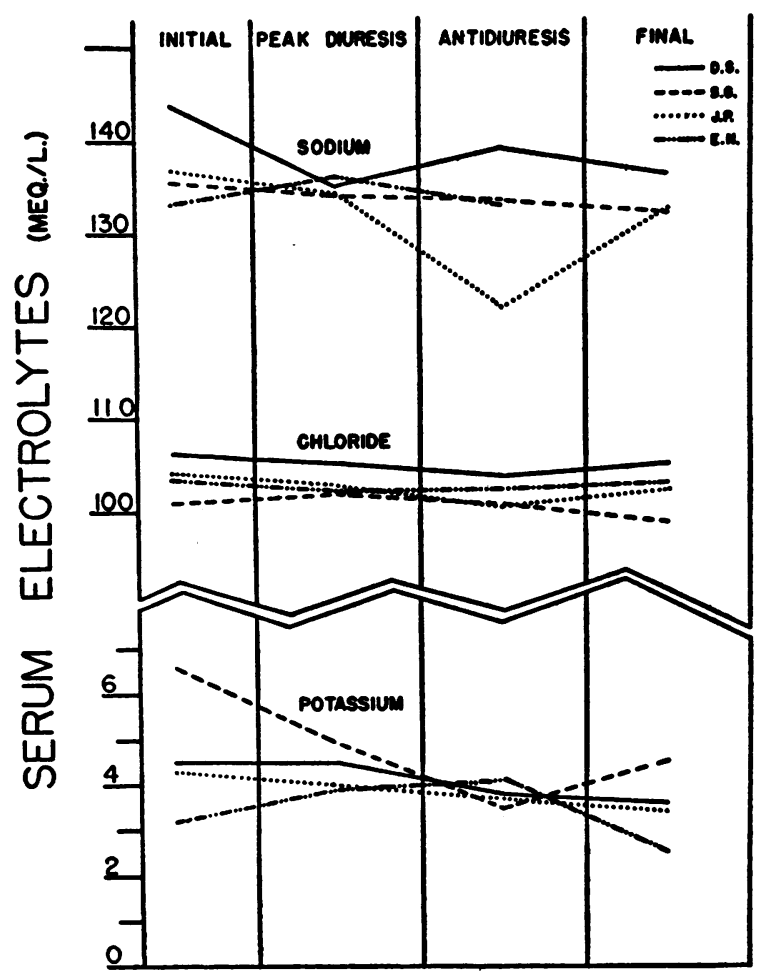

Fig. 2. The Effect of Intravenous Pitressin ( 0.57 mU/Kg.) on the Concentrations of Serum ElectroLytes in Control SubJects

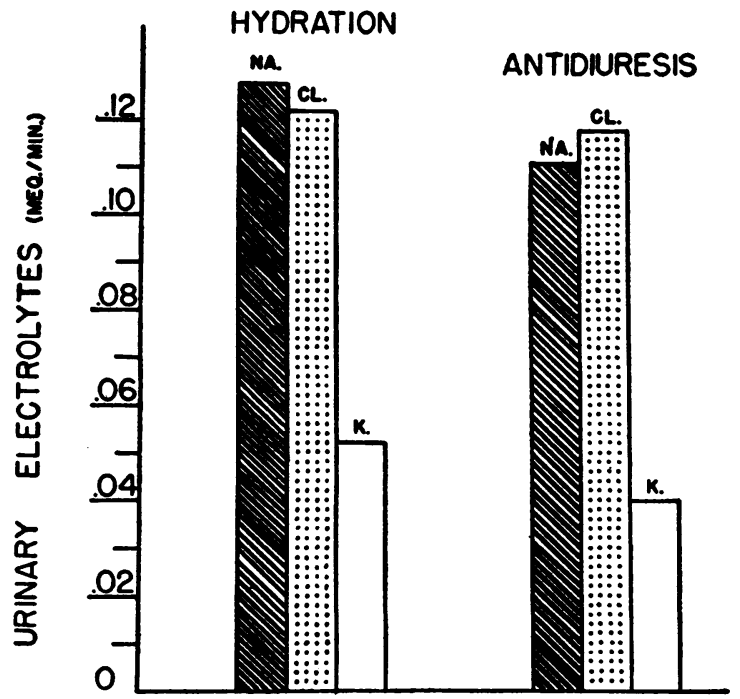

Fig. 3. The Effect of Intravenous Pitressin (0.57 MU/KG.) on the Average Urinary ExCretion of Electrolytes in 11 Patients (Four Patients with Liver Disease and Seven Control Subjects)

Statistical analysis showed no significant difference between the two groups of patients with respect to the effect of Pitressin on the urinary electrolytes. 
A number of patients received a second intravenous dose of Pitressin about 15 minutes after the antidiuretic effect of the first dose had subsided. In all instances, the effects of the second dose resembled those of the first with respect to the per cent inhibition and the effect on the electrolyte excretion. This result confirmed the fact that the physiological activity of the first dose had subsided. The second doses tended to produce somewhat smaller "per cents" of inhibition, but this was probably caused by the increased state of hydration which resulted from the inhibition of diuresis by the first dose (45).

The four experiments in which multiple intravenous doses of Pitressin were administered yielded antidiuresis curves which were identical for the two patients with cirrhosis of the liver and the control subject.

$B$. Serum electrolytes. In the patients with liver disease the concentration of serum sodium tended to fall during the periods of diuresis and Pitressin antidiuresis (Figure 1, Table V), while in the control subjects there were no such consistent changes (Figure 2, Table V). The concentrations of potassium and chloride in the serum

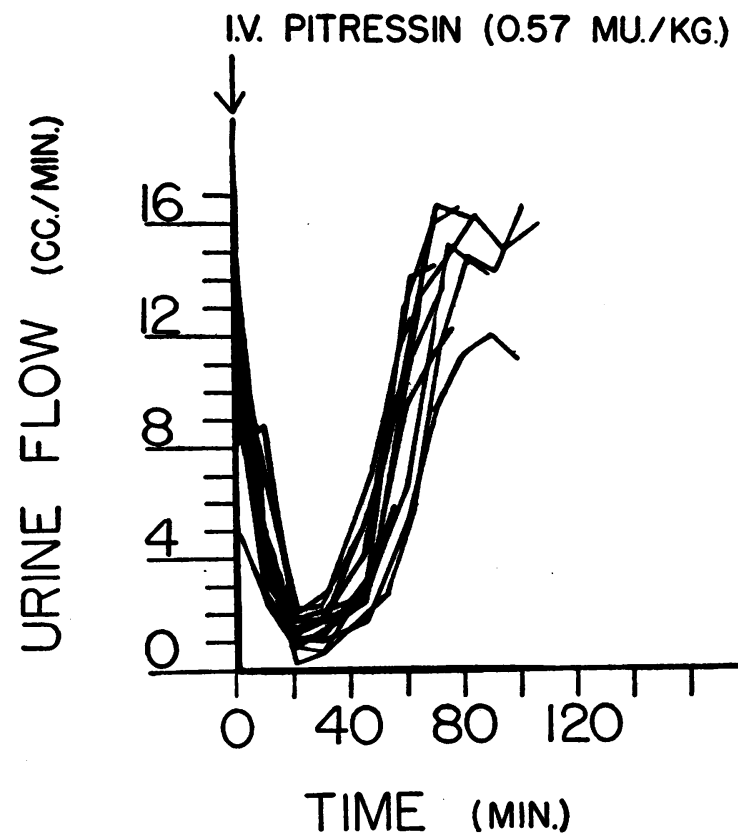

Fig. 4. The Effect of Intravenous Pitressin (0.57 MU/Kg.) ON The URine Flow in Continuously-Hydrated (INTravenous 5\% Glucose in Water) SubJECTS WITH AND WITHOUT LIVER DISEASE

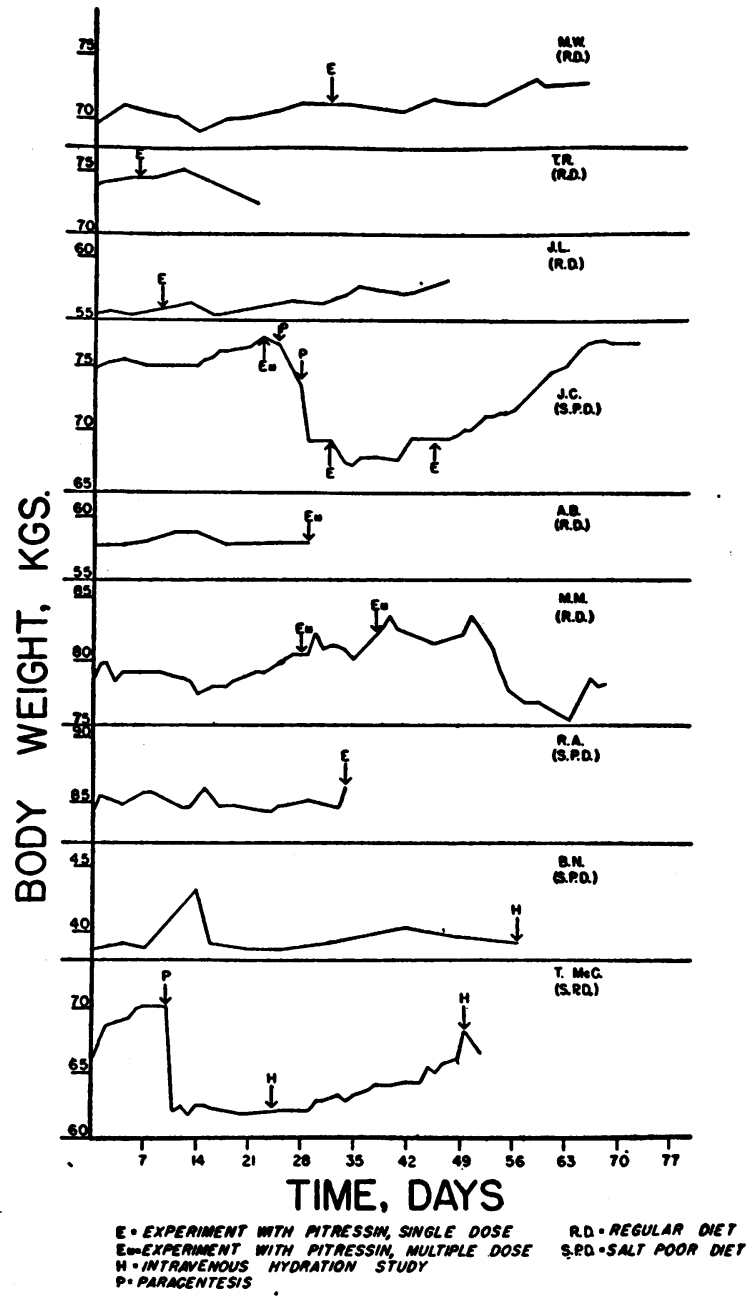

Fig. 5. The Body Weights of Nine Patients with LIVER Disease

showed no significant patterns of change during the entire experimental period, either in the patients with or without liver disease (Figures 1, 2, Table V).

C. Urinary electrolytes. Employing the method of "paired differences" we could demonstrate no statistically significant difference in the excretion of urinary sodium, chloride or potassium ( $\mathrm{mEq} . / \mathrm{min}$.) between the "hydration period" and the "antidiuresis period" in either group of experimental subjects (Table VI, Figure 3 ).

It will also be noted in Table VI that patients J. L., J. C. and T. R. (with liver disease) showed constantly lowered rates of urinary excretion of chloride and sodium in both the "hydration" and "antidiuresis" periods. 
TABLB I

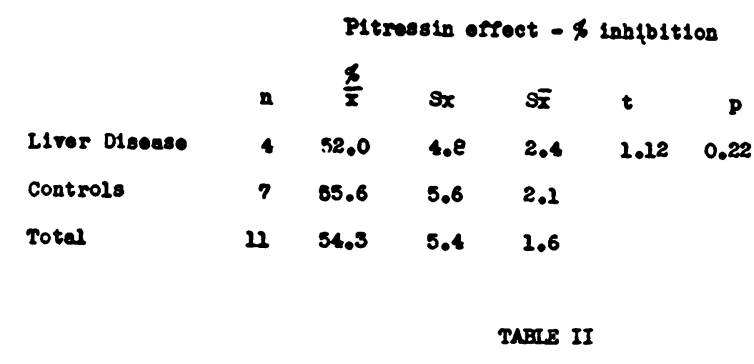

Duration of pitressin antidiuresis (min.)

min.

$\begin{array}{lllllll}\text { L1ter D1s04se } & 4 & 68.8 & 9.5 & 4.8 & 0.88 & 0.45 \\ \text { Controls } & 7 & 63.8 & 9.2 & 3.5 & & \end{array}$

TABLE III

Timo (min.) requirod to reach poak diuresis (cc/min)

(Hijdration porlod)

min.

$\begin{array}{lllllll}\text { I1tor D1soase } & 4 & 94.5 & 27.5 & 13.8 & 0.51 & 0.65\end{array}$

TABCE IV

Average urine flow during total hydration period

ce/min.

$\begin{array}{lllllll}\text { Liver D1soase } & 4 & 7.3 & 1.6 & 0.8 & 0.25 & 0.80 \\ \text { Controls } & 7 & 7.6 & 2.0 & 0.8 & & \end{array}$

$\bar{x}=$ man.

$S_{x^{\prime}}=$ Standard doriation.

$s_{\bar{x}}^{x}=$ Standard orror of tho mon.

$t=\frac{\bar{d}}{S_{\bar{d}}}$, where $\bar{d}-d$ dfference botween the moans

$\left(s_{\bar{d}}\right)^{2} \cdot\left(s_{1} \bar{x}\right)^{2}+\left(s_{2} \bar{x}\right)^{2}$.



\section{DISCUSSION}

The uniformity of responses to Pitressin in our experimental subjects is significant (Figure 4). Difficulties with other types of measurement of Pitressin effect have centered around the method of hydrating the test organisms, and the best way of quantitatively expressing Pitressin activity. These difficulties apparently have been overcome by using continuous intravenous infusions and by expressing the Pitressin effect in terms of "per cent inhibition."

In response to physiological doses of intravenous Pitressin ( 0.57 milliunits per $\mathrm{Kg}$.), the patients with liver disease behaved in the same manner as the controls with respect to the duration of Pitres- sin effect and the magnitude of response (per cent inhibition).

These results indicate that in this series of patients with liver disease there is no defect in the mechanism or mechanisms of inactivation of $\mathrm{Pi}$ tressin injected intravenously in physiological dosage.

To what extent is the similarity in rates of inactivation of Pitressin in patients with and without liver disease comparable with those of endogenous antidiuretic hormone? Table III helps to answer this question partially. It will be noted that the time required for peak diuresis to be reached was essentially the same for the two groups of experimental subjects, 94.5 minutes for those with hepatic 
dysfunction and 85.1 minutes for the controls. This similarity suggests that the endogenous antidiuretic hormone in patients with hepatic dysfunction is inactivated at the same rate as that in control subjects, whatever the mechanism of inactivation may be (destruction, detoxification, excretion, or some combination of these processes).

These data on the inactivation of Pitressin and of endogenous antidiuretic hormone lead to certain speculations. As mentioned above, there have been reports of increased amounts of an antidiuretic substance in the sera and urines of certain patients with liver disease. If this material represents the posterior pituitary antidiuretic hormone, these increased amounts may be due to overproduction by the posterior lobe of the pituitary, decreased inactivation by the liver and by any extrahepatic mechanisms that may exist, or to a combination of the two processes. If exogenous Pitres$\sin$ is also inactivated by the same mechanisms and at equivalent rates as endogenous posterior pituitary antidiuretic hormone, then our data would suggest that the inactivating mechanisms are capable of handling normal amounts of endogenous antidiuretic hormone in patients with liver cirrhosis. Therefore, it would seem that the reported increases in serum and urinary contents of anti- diuretic material in such patients are the result of overproduction. This conclusion follows only if the above premises are accepted, but involves us in no assumptions concerning the chemical identity of Pitressin and endogenous posterior pituitary antidiuretic hormone.

That patients with liver disease often show impaired water diuresis following oral hydration has been noted $(1-4)$. It is therefore of interest to consider the urine flows observed during the intravenous hydration periods in patients with positive water balance as manifested by increasing ascites. The levels of peak diuresis attained by the patients with liver disease $(13.0,11.8,12.9,14.6$ cc./min. for the four patients listed in Table VI and 18.1, 14.8, 6.4, 8.6, 9.0 for the other five) are comparable to those reached by the control subjects $(14.0,14.7,11.2,14.6,11.2,12.2,6.8)$. In addition, Table VI shows that the average urine flows for each patient during the "pre-Pitressin control period" are also comparable for the two groups of subjects, with some tendency, perhaps, for the hepatic patients' flows to be a little lower. The urine flows during the total hydration period averaged $7.3 \mathrm{cc} . / \mathrm{min}$. for the patients with hepatic dysfunction, and $7.6 \mathrm{cc} . / \mathrm{min}$. for the control patients. The uniform trend toward relatively high

TABLE V

Effect of Pitressin on serum electrolytes

\begin{tabular}{|c|c|c|c|c|c|c|c|c|c|c|c|c|}
\hline \multirow[b]{2}{*}{ ItTer D1sease } & \multicolumn{3}{|c|}{. INITIAI } & \multicolumn{3}{|c|}{. DIURESIS } & \multicolumn{3}{|c|}{ ANTIDIURESIS } & \multirow{2}{*}{$\begin{array}{l}\mathrm{F} I \\
\mathrm{Na} \\
\mathrm{mBg} / \mathrm{L}\end{array}$} & \multirow{2}{*}{$\begin{array}{l}N A \\
C 1 \\
\mathrm{~m} R \mathrm{~g} / \mathrm{I}\end{array}$} & \multirow{2}{*}{$\begin{array}{l}I \\
K \\
m s g / L\end{array}$} \\
\hline & $\begin{array}{c}N a \\
m i s / L\end{array}$ & $\begin{array}{c}\text { GI } \\
m B q / L\end{array}$ & $\begin{array}{c}\mathbf{K} \\
\mathrm{mBq} / \mathbf{I}\end{array}$ & $\begin{array}{l}\mathrm{Na} \\
\mathrm{mis} g / \mathrm{I}\end{array}$ & $\begin{array}{c}\mathrm{Cl} \\
\mathrm{mBq} / \mathrm{L}\end{array}$ & $\begin{array}{c}\mathrm{x} \\
\mathrm{m} \mathrm{sq} / \mathrm{I}\end{array}$ & $\begin{array}{l}\mathrm{Na} \\
\mathrm{mig} / \mathrm{L}\end{array}$ & $\begin{array}{c}\mathrm{cl} \\
\mathrm{mBg} / \mathrm{I}\end{array}$ & $\begin{array}{c}\mathrm{K} \\
\mathrm{mis} g / \mathrm{L}\end{array}$ & & & \\
\hline y.l. & $143.5^{*}$ & 108.0 & 3.8 & $138.1^{*}$ & 105.4 & 3.1 & $131.4^{*}$ & 104.5 & 2.3 & $132.5^{*}$ & 105.3 & 3.4 \\
\hline J.I. & $234.1 *$ & 96.2 & 3.2 & $130.9^{*}$ & 93.4 & 3.9 & $120.5^{*}$ & 93.0 & 3.4 & $130.9^{*}$ & 93.4 & 3.6 \\
\hline J.C. & 140.2 & 109.8 & 4.2 & 134.0 & 106.0 & 4.0 & 131.0 & 106.2 & 4.2 & 228.6 & 106.6 & 4.0 \\
\hline T.P. & 133.0 & 101.8 & Qus & 127.8 & 101.0 & 2.8 & 123.0 & 97.6 & 3.7 & 127.0 & 98.2 & 3.7 \\
\hline controlo & & & & & & & & & & & & \\
\hline D.S. & $143.9^{*}$ & 206.2 & 4.5 & $135.2^{*}$ & 205.2 & 4.5 & $139.2^{*}$ & 103.8 & 3.8 & $136.4^{*}$ & 105.0 & 3.6 \\
\hline S.G. & $135.6^{*}$ & 101.0 & 6.5 & $134.2^{*}$ & 102.0 & 4.9 & $133.8^{*}$ & 100.8 & 3.6 & $132.2^{*}$ & 98.8 & 4.5 . \\
\hline J.P. & $136.8^{*}$ & 104.2 & 4.3 & $134.3^{*}$ & 103.0 & 4.0 & $122.1^{*}$ & 100.6 & 3.7 & $132.1^{*}$ & 102.3 & 3.4 \\
\hline E.N. & $135.3^{*}$ & 103.5 & 3.2 & $136.8^{*}$ & 102.1 & 3.9 & $133.4^{*}$ & 102.4 & 4.1 & Qus & 103.1 & 2.5 \\
\hline
\end{tabular}


TABLE VI

Urinary electrolyte excretion during hydration and Pitressin antidiuresis

\begin{tabular}{|c|c|c|c|c|c|c|c|c|c|c|c|c|c|c|}
\hline \multirow[b]{2}{*}{ Patiente } & \multirow[b]{2}{*}{$\begin{array}{l}\text { TImo } \\
\text { n1s. }\end{array}$} & \multirow[b]{2}{*}{$\begin{array}{l}\text { Orino } \\
\text { nom } \\
\text { cofan. }\end{array}$} & \multicolumn{3}{|c|}{ Fyaretion (B) } & \multicolumn{5}{|c|}{ Ant1diuroese (A) } & \multicolumn{4}{|c|}{ (B) monus (A) } \\
\hline & & & $\begin{array}{l}C 1 \\
\frac{m a g}{a 1 n} .\end{array}$ & $\begin{array}{l}\mathrm{sa} \\
\frac{m a}{\min }\end{array}$ & $\begin{array}{l}x \\
\frac{\cos s}{\sin n} .\end{array}$ & $\begin{array}{l}\text { TImo } \\
\text { min. }\end{array}$ & $\begin{array}{l}\text { Urine } \\
\text { nom } \\
\text { oo/min. }\end{array}$ & $\begin{array}{l}\text { CI } \\
\frac{\operatorname{ming}}{\min .}\end{array}$ & $\begin{array}{l}m \\
\frac{m}{m i n} .\end{array}$ & $\begin{array}{l}x \\
\frac{-50}{m n_{0}}\end{array}$ & $\begin{array}{l}\text { Orino } \\
\text { now } \\
\text { co/min. }\end{array}$ & $\begin{array}{l}a \\
\text { mina }\end{array}$ & $\begin{array}{l}\text { Na } \\
\frac{\text { san }}{\min .}\end{array}$ & $\begin{array}{l}x \\
\frac{m a}{m_{0}} a_{0}\end{array}$ \\
\hline $\begin{array}{l}\text { Liver } \\
\text { DI seoesed }\end{array}$ & & & & & & & & & & & & & & \\
\hline$x_{0} \pi_{0}$ & 70.3 & 9.67 & .211 & .280 & .050 & 70.3 & 6.07 & .201 & .256 & .064 & $3.60+$ & $+.010+$ & $+.024-$ & -.014 \\
\hline J.L. & 79.4 & 9.70 & .022 & .032 & .026 & 79.4 & 4.46 & .031 & .022 & .039 & $5.24-$ & $-.009+$ & $+.010-$ & -.013 \\
\hline J.C. & 69.1 & 9.76 & .034 & .004 & .054 & 69.1 & 7.06 & .062 & .004 & .056 & 8.70 & $-.028+$ & $+.0005-$ & -.002 \\
\hline $\begin{array}{l}T_{0} R_{0} \\
\text { Controls }\end{array}$ & 56.2 & 23.38 & .028 & .014 & .055 & 56.2 & 5.37 & .025 & .008 & .026 & $8.01+$ & $+.005+$ & $+.006+$ & +.028 \\
\hline D.S. & 59.5 & 12.86 & .23 & .227 & .055 & 39.5 & 5.05 & .245 & .225 & .049 & $7.81-$ & $-.015+$ & $+.002+$ & +.006 \\
\hline R..D. & 60.0 & 21.48 & .022 & .010 & .024 & 60.0 & 6.43 & .021 & .008 & .019 & $5.05+$ & $+.001+$ & $+.002+$ & +.005 \\
\hline J.P• & 60.3 & 9.70 & .143 & .199 & .037 & 60.3 & 4.11 & .161 & .202 & .031 & $5.59-$ & $-.018-$ & $-.003+$ & +.006 \\
\hline s.X.P. & 81.1 & 12.30 & .241 & .250 & .124 & 82.1 & 5.22 & .134 & .139 & .044 & $7.08+$ & $+.107+$ & $+.111+$ & +.080 \\
\hline M.I. & 68,9 & 9.32 & .053 & .061 & .030 & 68.9 & 5.25 & .128 & .113 & .028 & $4.07-$ & -.075 & $-.052+$ & +.002 \\
\hline s.c. & 64.7 & 11.71 & .235 & .204 & .105 & 64.7 & 6.00 & .172 & .136 & .047 & $5.72+$ & $+.063+$ & $+.068+$ & +.058 \\
\hline E.B. & 52.2 & 5.97 & - & - & .024 & 52.2 & 2.42 & - & - & .036 & 3.55 & - & - & -.012 \\
\hline $\bar{x}$ & 61.5 & 10.5 & .122 & .128 & .053 & 65.6 & 5.22 & $.118^{\circ}$ & .111 & .040 & $5.31+$ & $+.0039+$ & $+.0168+$ & +.013 \\
\hline $5 x$ & 9.4 & 2.1 & .099 & .113 & .035 & 9.17 & 1.26 & .000 & .097 & .014 & 1.8 & .0498 & .0439 & .0305 \\
\hline s: & 2.84 & . & .031 & .036 & .0099 & 2.77 & .38 & .025 & .031 & .004 & .542 & .0157 & .0139 & .009 \\
\hline$t$ & & & & & & & & & & & $\begin{array}{l}9.8 \\
.0001\end{array}$ & $\begin{array}{l}.248 \\
.84\end{array}$ & $\begin{array}{l}1.2 \\
.23\end{array}$ & $\begin{array}{l}1.41 \\
.17\end{array}$ \\
\hline
\end{tabular}

"Pre-Pitressin control period" $(\mathrm{H})$ is that portion of the intravenous hydration period which just precedes the Pitressin injection, and which is equal in time to the "antidiuresis period" for a given patient.

$* \overline{\mathrm{x}}$ for $(\mathrm{H})$ minus $(\mathrm{A})=$ difference between the means $=\overline{\mathrm{d}}$.

$\overline{\mathbf{x}}=$ mean.

$\mathrm{S}_{\mathbf{x}}=$ Standard deviation.

$\mathrm{S}_{\overline{\mathbf{x}}}=$ Standard error of the mean.

$t=\frac{\bar{d}}{S_{\bar{d}}}$, where $\bar{d}=$ difference between the means and $S_{\bar{d}}=S_{\bar{x}}$ for $(H)$ minus $(A)$.

$p=$ probability if $p=1.0$, then the observed difference is entirely a chance occurrence.

if $p=0.0$, then there is no element of chance.

urine flows in these patients with liver disease under these experimental conditions is noteworthy in view of the fact that in at least six of the nine patients, ascites was accumulating and the body weight was increasing (Figure 5).

Table VI indicates that the average urinary excretions of sodium and chloride for J. L., J. C. and $T$. R. were markedly depressed even when their average urine flows were quite high, demonstrating a definite dissociation between the excretion of water and of sodium and chloride, and furnishing added support to the clinical evidence for decompensated liver disease. J. C. was the only one of the four patients with liver disease who was on a low-salt regimen; the other three had no restrictions placed on their salt intake. 
TABLE VII

The effect of posterior pituitary extracts on the urinary excretion of electrolytes

\begin{tabular}{|c|c|c|c|c|c|c|c|}
\hline Tost Organ1am & zutract & $\begin{array}{l}\text { Boute of Me- } \\
\text { minl stration }\end{array}$ & & $\operatorname{men}_{0 \times 10}$ & eet & Ineretica & Perenence \\
\hline \multirow[b]{2}{*}{ Bunen } & \multirow[b]{2}{*}{ P1troseln $8000=0$} & \multirow[b]{2}{*}{ s.Q. } & ria & $\mathbf{a}$ & $\mathbf{x}$ & In Terme os & \multirow[b]{2}{*}{ Manducotes, 15ae } \\
\hline & & & + & + & - & 8 & \\
\hline Buman & P1tressin 10000 m & IM. & & \pm & & 8 & Ilttle et al, 1909 \\
\hline Fuman & P1trosein $1-3 \mathrm{mo} / \mathrm{K}_{8}$. & I.V. & \pm & \pm & & & Murphy, 1860 \\
\hline Buman & P1trosoln $10-100=0$ & I.V. & \pm & \pm & & $Q$ & $\begin{array}{l}\text { Sincalals-sindth et al } \\
1960\end{array}$ \\
\hline Buman & $\begin{array}{ll}\text { P1 trossin } & 20-100 \mathrm{md} \\
\text { P1tooln } & 50-200 \mathrm{~m} \\
\text { Post. P1t. } 100-200 \mathrm{~m} \\
\text { Lobo Ext. }\end{array}$ & $\begin{array}{l}\text { I.V. } \\
\text { I.V. } \\
\text { I.V. }\end{array}$ & $\frac{ \pm}{ \pm}$ & $\begin{array}{l} \pm \\
\pm \\
\pm\end{array}$ & & $\begin{array}{l}Q \\
Q \\
Q\end{array}$ & $\begin{array}{l}\text { Chalmers } \\
\text { et al, } 1998\end{array}$ \\
\hline Buman & P1trosein .57 mo/KB & I.V. & \pm & \pm & \pm & $\mathbf{Q}$ & Wh1te et al, 1962 \\
\hline DOB & $\begin{array}{ll}\text { P1trossin } 15-20 \mathrm{mo} / \mathrm{hr} \\
\text { P1tooln } & 26 \mathrm{mo} / \mathrm{hr} .\end{array}$ & $\begin{array}{l}\text { I.V. } \\
\text { I.V. }\end{array}$ & & $\begin{array}{l}+ \\
\pm\end{array}$ & & $\begin{array}{l}\text { Q } \\
\mathbf{e}\end{array}$ & $\begin{array}{l}\text { Anslow et al, } \\
1948\end{array}$ \\
\hline Do8 & P1trosein . $4-10=0 / K_{8}$ & I.V. & + & & + & $\mathbf{Q}$ & $\begin{array}{l}\text { Sartorius \& Roberts, } \\
1949\end{array}$ \\
\hline $\begin{array}{l}\text { Cat } \\
\text { (norral \& } \\
\text { diabotos in- } \\
\text { s1pldus) }\end{array}$ & $\begin{array}{l}\text { P1tros81n } 3000 \text { mo } \\
\text { Parloo-Dav1s }\end{array}$ & S.Q. & $\begin{array}{l}\text { (No } \\
\text { Na, }\end{array}$ & $\begin{array}{l}\text { offe } \\
\mathrm{B} \text {, }\end{array}$ & et 0 & on sorum & Winter et 2l, 1959 \\
\hline Pat & $\begin{array}{l}\text { Postorior } 1500 \mathrm{mo} / 100 \mathrm{~m} . \\
\text { P1tultary } \\
\text { Soln. } \\
\text { Squ1bb }\end{array}$ & $I . P \bullet$ & & + & & Q & Silvette, 1940 \\
\hline Rant & $\begin{array}{l}\text { Posterior } 2.5 \mathrm{mo} / 100 \mathrm{mom} \\
\text { Pltultary to } 3000 \mathrm{~mol} / 100 \mathrm{~m} \\
\text { Soln. } \\
\text { Squibo }\end{array}$ & I.P. & & $t$ & & c & silvette, 1940 \\
\hline Rat & $\begin{array}{l}\text { Postorior } 250-500 \mathrm{~m} 0 \\
\text { P1tu1tery } \\
\text { Soln. } \\
\text { Squibb }\end{array}$ & S.Q. & & $t$ & & c & Corey \& Britton, 194 \\
\hline Rat & $\begin{array}{l}\text { Obstetrical } \\
\text { Pitultrin } \\
\text { Parke-Davls }\end{array} \quad 100=0 / 100$ & & & + & & Q & EAM, 1943 \\
\hline nat & 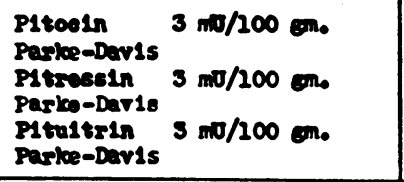 & $\begin{array}{l}\text { s.Q. } \\
\text { s.Q. } \\
\text { s.Q. }\end{array}$ & & $\begin{array}{l}+ \\
\pm \\
+\end{array}$ & & $\begin{array}{l}Q \\
Q\end{array}$ & $\begin{array}{l}\text { Dlaber * talles. } \\
2946\end{array}$ \\
\hline Mouse & 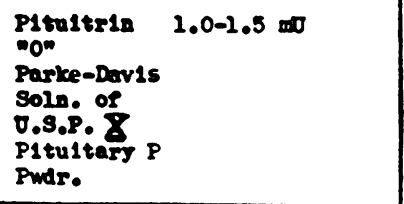 & I.P. & & + & & Q & $\begin{array}{l}\text { Noloon \& :loode, } \\
\text { 1934 }\end{array}$ \\
\hline Opposeres & $\begin{array}{l}\text { Poster10r } \quad 6000 \mathrm{mo/K} 8 . \\
\text { P1tu1tary } \\
\text { Soln. } \\
\text { Squ1bb }\end{array}$ & s.Q. & & + & & $Q$ & $\begin{array}{l}\text { S11rotto \& Britten, } \\
1938\end{array}$ \\
\hline Tros & $\begin{array}{l}\text { P1tuitrin } 500 \text { mo/10 om. } \\
\text { Surg1cel } \\
\text { Parke-Dar10 } \\
\text { P1treselo } \\
\text { Pltoele }\end{array}$ & $\begin{array}{l}\text { Doreal } \\
\text { Lymph } \\
\text { See }\end{array}$ & $\begin{array}{l} \pm \\
\pm \\
\pm\end{array}$ & $\begin{array}{l} \pm \\
\pm \\
\pm\end{array}$ & & $\begin{array}{l}\mathbf{Q} \\
\mathbf{Q} \\
\mathbf{Q}\end{array}$ & Boyd a mito, 1959 \\
\hline
\end{tabular}

$+=$ increased excretion in urine.. $\quad C=$ concentration.

\pm variable effect

- $=$ decreased.
$Q=$ quantity per unit time.
Route of Administration

I.M. = in tramuscular. I.V. = intravenous.

I.P. = intra peritoneal. S.Q. = subcutaneous. 
The fact that in the patients with liver disease the concentration of sodium in the serum tended to fall during the periods of diuresis and antidiuresis, is interesting. Since there was no change in the urinary excretion of sodium during the antidiuresis period, this fall in the serum concentration during Pitressin antidiuresis might signify either a dilution of the blood or a shift of sodium from the extracellular spaces. Lack of consistent changes in the hematocrit or in the concentrations of potassium and chloride in the serum tends to exclude dilution of the serum. Why sodium should should move out of the extracellular space in the patients with liver disease, but not in the control subjects, is not clear at present. Perhaps later studies on more patients will elucidate this point. We are presenting this particular datum at this time for the prime purpose of bringing it to the attention of others who may be in a position to confirm it.

Parenthetically, six patients with congestive heart failure and one with diabetes insipidus, did not show such a decrease in serum sodium during Pitressin antidiuresis.

Three groups of investigators $(27,28,39)$ administered Pitressin intravenously to humans in amounts roughly approximating the dosage we employed. In no instance did the Pitressin have a significant effect on the urinary excretion of sodium and chloride. Our experiments confirmed this lack of effect of Pitressin, in the dosage employed, on the urinary excretion of sodium and chloride. In addition, we demonstrated that the Pitressin had no significant effect on the excretion of potassium ( $\mathrm{mEq} . / \mathrm{min}$.) in the urine.

Table VII shows the diversity of experiments on the effect of posterior pituitary gland extracts on electrolyte metabolism. Because there have been such differences in the experimental protocols with respect to the nature of the gland extracts, the dosages, the routes of administration, and the test animals studied, it is difficult to compare the various results.

\section{SUMMARY AND CONCLUSIONS}

1. A method of studying Pitressin antidiuresis is presented.

2. $0.57 \mathrm{mU}$ of Pitressin per $\mathrm{Kg}$. administered intravenously produced $52.0 \%$ inhibition of diu- resis in the patients with liver disease and 55.6\% inhibition in the controls.

3. The Pitressin effect lasted 68.8 minutes in the liver disease group and 63.8 minutes in the controls.

4. There was no significant difference between the two groups of patients with respect to the time required for peak diuresis to be reached ( $94.5 \mathrm{~min}-$ utes for hepatic dysfunction group and $85.1 \mathrm{~min}-$ utes for the controls).

5. The average urine flow during the "hydration period" did not vary significantly between the two groups.

6. From these results it would seem that there is no defect in the mechanism of inactivation of Pitressin injected in physiological dosage in this series of patients with liver disease. The possibility of overproduction of antidiuretic hormone in these patients is discussed and evaluated.

7. Under our experimental conditions, 0.57 $\mathrm{mU} / \mathrm{Kg}$. of Pitressin, injected intravenously, did not affect significantly the urinary excretion of sodium, chloride, or potassium, but tended to cause a decrease in the concentration of serum sodium only in the patients with liver disease.

\section{APPENDIX}

Case reports of the four patients with liver disease in whom the responses to single intravenous injections of Pitressin were studied:

M. W.: M. H. No. 48798. Forty-two year old white female who was admitted on August 30, 1949, with a history of recurrent epistaxis all of her life and of icterus for one month. For two years prior to admission she had drunk a pint of wine per day. One month prior to her present admission a liver biopsy was performed at another hospital. The slides were reviewed at this hospital and showed cirrhosis of the liver. On admission she was markedly icteric, had spider angiomata across the chest and on the arms and shoulders, and enlarged abdominal veins. The liver was palpable at the iliac crest and the spleen was felt 3 to 4 fingerbreadths below the costal margin. No peripheral edema was present on admission and there was questionable ascites, but she developed edema of the ankles by the time she was studied by us. Chemical studies of the serum showed: total protein $7.3 \mathrm{gm} . \%$, albumin $3.1 \mathrm{gm} . \%$, globulin $4.2 \mathrm{gm} . \%$; serum bilirubin $10.8 \mathrm{mg} . \%$; cephalin flocculation $3+$ to $4+$; thymol turbidity ranged between 13 and 8 units. Urinary urobilinogen was present only in the undiluted specimen but later was present in dilutions of 1:80. Stools were positive for bile and urobilinogen.

J. C. : M. H. No. 50293. Fifty-six year old white male in whom a diagnosis of portal cirrhosis first was made 
in 1938, when he suffered from vomiting, eructations, abdominal cramps and dizziness; at this time the liver was enlarged to 2 fingerbreadths below the costal margin and the tip of the spleen was palpable. On his admission on March 1, 1950, the abdomen was distended with fluid, with a fluid wave and shifting dullness. After abdominal paracentesis the liver was felt to be hard, nodular, enlarged to $21 / 2$ fingerbreadths below the costal margin, and the splenic edge was felt 2 fingerbreadths below the left costal margin. Chemical studies of the serum included: albumin $2.2 \mathrm{gm} . \%$, globulin $3.5 \mathrm{gm} . \%$; total cholesterol $188 \mathrm{mg} . \%$, esters $115 \mathrm{mg} . \%$; alkaline phosphatase 9.6 Bodansky units per $100 \mathrm{cc}$; bilirubin $2.1 \mathrm{mg} . \%$; $93 \%$ retention of bromsulphalein in 45 minutes. The urine was negative for bile and positive for urobilinogen in 1:40 dilution. Two abdominal paracenteses yielded $3,000 \mathrm{cc}$. and $4,650 \mathrm{cc}$., respectively. Thiomerin did not help to diminish the ascites.

J. L.: M. H. No. 50740. Fifty year old white Italian male with past history of malaria at the age of eight years. For $31 / 2$ months prior to his admission he had been noticing weakness and mild loss of appetite. About six weeks before his admission the weakness increased, his limbs began to ache, and he was given penicillin. On the day prior to his admission he developed painless jaundice. He had been in the habit of taking one to two glasses of wine per day. Physical examination on admission showed skin and scleral icterus, hepatosplenomegaly (liver 5 to 6 fingerbreadths below the costal margin and the spleen 2 fingerbreadths), and fever. The urine on admission was positive for bile and positive for urobilinogen in 1:10 dilution. The feces were positive for bile and negative for blood throughout the hospital stay. Chemical studies of the serum showed: total protein $6.8 \mathrm{gm} . \%$, albumin 4.3 , globulin 2.5; bilirubin $10.7 \mathrm{mg} . \%$; thymol turbidity 9; total cholesterol $272 \mathrm{mg} . \%$, esters $92 \mathrm{mg} . \%$; cephalin flocculation $4+$; alkaline phosphatase 13.7 Bodansky units per $100 \mathrm{cc}$.

T. R.: M. H. No. 46641. Fifty-two year old white female with onset of anorexia and epigastric pain five years prior to admission, in April 1950. In 1948, the patient had ascites and jaundice, and the diagnosis of cirrhosis of the liver was established by biopsy of the liver. Physical examination on admission showed icterus, teleangectasias on the skin, and ecchymotic areas over the tibiae. The liver was enlarged 3 to 4 fingerbreadths below the costal margin, and fluid was felt to be present in the abdomen. An esophagram revealed the presence of varices. The urine contained bile and also contained urobilinogen at a 1:320 dilution. Serum albumin was $3.3 \mathrm{gm} . \%$, globulin 3.4 gm.\%; thymol turbidity was normal; cephalin flocculation was $3+$, cholesterol $197 \mathrm{mg} . \%$, esters 128; alkaline phosphatase 5.3 Bodansky units per $100 \mathrm{cc}$; bilirubin 6.5 mg.\%.

\section{REFERENCES}

1. Gilbert, A., and Lereboullet, P., Des urines retardées (opsiurie) dans les cirrhoses. Compt. rend. Soc. de Biol., 1901, 53, 276.
2. Adlersberg, D., and Fox, C. L., Jr., Changes of the water tolerance test in hepatic disease. Ann. Int. Med., 1943, 19, 642.

3. Labby, D. H., and Hoagland, C. L., Water storage and the movements of body fluids and chlorides during acute liver disease. J. Clin. Invest., 1947, 26, 343.

4. Leslie, S., Stueck, G. H., Jr., Shorr, H. M., and Ralli, E. P., Chemical and physiological changes during water tolerance tests in patients with cirrhosis. Federation Proc., 1948, 7, 71.

5. Ralli, E. P., Robson, J. S., Clarke, D., and Hoagland, C. L., Factors influencing ascites in patients with cirrhosis of the liver. J. Clin. Invest., 1945, 24, 316.

6. Hall, C. A., Frame, B., and Drill, V. A., Renal excretion of water and antidiuretic substances in patients with hepatic cirrhosis and rats with dietary liver injury. Endocrinology, 1949, 44, 76.

7. Lloyd, C. W., and Lobotsky, J., Serum antidiuretic substances and urinary corticosteroid in the human. J. Clin. Endocrinol., 1950, 10, 318.

8. Ames, R. G., Moore, D. H., and Van Dyke, H. B., The excretion of posterior pituitary antidiuretic hormone in the urine and its detection in the blood. Endocrinology, 1950, 46, 215.

9. Drill, V. A., and Frame, B., Antidiuretic activity of liver extracts and of urine from patients with hepatic cirrhosis. Federation Proc., 1948, 7, 215.

10. Heller, H., and Urban, F. F., The fate of the antidiuretic principle of posterior pituitary extracts in vivo and in vitro. J. Physiol., 1935, 85, 502.

11. Eversole, W. J., Birnie, J. H., and Gaunt, R., Inactivation of posterior pituitary antidiuretic hormone by the liver. Endocrinology, 1949, 45, 378.

12. Birnie, J. H., Inactivation of posterior pituitary antidiuretic hormone by liver extracts. Federation Proc., 1950, 9, 12.

13. Baez, S., Mazur, A., and Shorr, E., Hepatorenal factors in circulatory homeostasis. XX: Antidiuretic action of hepatic vasodepressor, VDM (ferritin). Am. J. Physiol., 1950, 162, 198.

14. Baez, S., Shorr, E., and Zweifach, B., Personal communication.

15. Gilman, A., and Goodman, L., The secretory response of the posterior pituitary to the need for water conservation. J. Physiol., 1937, 90, 113.

16. Pickford, M., Control of the secretion of antidiuretic hormone from the pars nervosa of the pituitary gland. Physiol. Rev., 1945, 25, 573.

17. Verney, E. B., Absorption and excretion of water; the antidiuretic hormone. Lancet, 1946, 2, 739 and 781.

18. Burn, J. H., Estimation of the antidiuretic potency of pituitary (posterior lobe) extract. Quart. J. Pharm. \& Pharmacol., 1931, 4, 517.

19. Gibbs, O. S., A practical test for the antidiuretic action of pituitary. J. Pharmacol. \& Exper. Therap., 1930, 40, 129. 
20. Boyd, E. M., and Mack, E. G., A method of assaying pituitary water retention principle. Endocrinology, 1940, 26, 153.

21. Krieger, V. I., and Kilvington, T. B., Antidiuretic substance in urine in relation to normal and toxemic pregnancy. Med. J. Australia, 1940, 1, 575.

22. Jeffers, W. A., Livezey, M. M., and Austin, J. H., A method for demonstrating an antidiuretic action of minute amounts of pitressin: statistical analysis of results. Proc. Soc. Exper. Biol. \& Med., 1942, 50, 184.

23. Ham, G. C., Reproducible diuresis and chloruresis for bioassay of antidiuretic activity. Proc. Soc. Exper. Biol. \& Med., 1943, 53, 210.

24. Hare, K., Melville, E. V., Chambers, G. H., and Hare, R. S., The assay of antidiuretic material in blood and urine. Endocrinology, 1945, 36, 323.

25. Manchester, R. C., Influence of posterior pituitary extracts on mineral and water exchange in children. Proc. Soc. Exper. Biol. \& Med., 1932, 29, 717.

26. Little, J. M., Wallace, S. L., Whatley, E. C., and Anderson, G. A., Effect of pitressin on the urinary excretion of chloride and water in the human. Am. J. Physiol., 1947, 151, 174.

27. Sinclair-Smith, B. C., Sisson, J., Kattus, A. A., Genecin, A., Monge, C., McKeever, W., and Newman, E. V., The effects of posterior pituitary extract and smoking on water, sodium and chloride excretion in normal subjects and in patients with congestive cardiac failure. Bull. Johns Hopkins Hosp., 1950, 87, 221.

28. Chalmers, T. M., Lewis, A. A. G., and Pawan, G. L. S., The effect of posterior pituitary extracts on the renal excretion of sodium and chloride in man. $J$. Physiol., 1951, 112, 238.

29. Anslow, W. P., Jr., Wesson, L. G., Jr., Bolomey, A. A., and Taylor, J. G., Chloruretic action of pressorantidiuretic fraction of posterior pituitary extract. Federation Proc., 1948, 7, 3.

30. Sartorius, O. W., and Roberts, K., The effects of pitressin and desoxycorticosterone in low dosage on the excretion of sodium, potassium, and water by the normal dog. Endocrinology, 1949, 45, 273.

31. Winter, C. A., Ingram, W. R., and Gross, E. G., Effect of pitressin injections upon the serum electrolytes and water exchange of cats with diabetes insipidus and adrenal insufficiency. Am. J. Physiol., 1939, 127, 64.
32. Silvette, H., The influence of post-pituitary extract on the excretion of water and chlorides by the renal tubules. Am. J. Physiol., 1940, 128, 747.

33. Silvette, H., Effect of diminishing doses of postpituitary extract on urinary excretion of water and chlorides. Proc. Soc. Exper. Biol. \& Med., 1940, 45, 599.

34. Corey, E. L., and Britton, S. W., The antagonistic action of desoxycorticosterone and posterior-pituitary extract on chloride and water balance. Am. J. Physiol., 1941, 133, 511.

35. Dicker, S. E., and Heller, H., The renal action of posterior pituitary extract and its fractions as analysed by clearance experiments on rats. J. Physiol., 1946, 104, 353.

36. Nelson, E. E., and Woods, G. G., The diuretic-antidiuretic activity of posterior pituitary extracts. J. Pharmacol. \& Exper. Therap., 1934, 50, 241.

37. Silvette, H., and Britton, S. W., Renal function in the opossum and the mechanism of corticoadrenal and post-pituitary action. Am. J. Physiol., 1938, 123, 630.

38. Boyd, E. M., and Whyte, D. W., The effect of posterior hypophyseal extract on the retention of water and salt injected into frogs. Am. J. Physiol., 1939, 125, 415.

39. Murphy, R. J. F., Studies on the mechanisms of saline diuresis. J. Clin. Invest., 1950, 29, 836.

40. Peters, J. H., The determination of creatinine and creatine in blood and urine with the photoelectric colorimeter. J. Biol. Chem., 1942, 146, 179.

41. Butler, A. M., and Tuthill, E., An application of the uranyl zinc acetate method for determination of sodium in biological material. J. Biol. Chem., 1931, 93, 171.

42. Van Slyke, D. D., and Hiller, A., Application of Sendroy's iodometric chloride titration to proteincontaining fluids. J. Biol. Chem., 1947, 167, 107.

43. Benedict, S. R., The detection and estimation of glucose in urine. J. A. M. A., 1911, 57, 1193.

44. Mather, K., Statistical Analysis in Biology. Interscience Publishers, Inc., New York, 1947, 2nd ed.

45. Pickford, M., The inhibition of water diuresis by pituitary (posterior lobe) extract and its relation to the water load of the body. J. Physiol., 1936, 87, 291. 